\title{
A new genus, with a new species, from Brazil (Acari: Prostigmata: Cunaxidae)
}

\author{
TATIANE MARIE MARTINS GOMES DE CASTRO ${ }^{1} \& \mathrm{JACOB}^{\mathrm{N}}$ DEN HEYER ${ }^{2}$ \\ ${ }^{1}$ Departamento de Fitossanidade, UNESP, Campus de Jaboticabal, São Paulo, Brasil, 14884-900. \\ E-mail: tatianemarie@yahoo.com.br \\ ${ }^{2}$ Setor de Zoologia, Departamento de Entomologia, Fitopatologia e Zoologia Agrícola, Escola Superior de Agricultura "Luiz de \\ Queiroz", Universidade de São Paulo, Piracicaba, São Paulo, Brazil, 13418-900.E-mail: jacob.den.heyer@gmail.com \\ South African address: Department of Zoology and Entomology, University of the Free State, P.O. Box 339, Bloemfontein. \\ Website:www.uovs.ac.za
}

\begin{abstract}
A new cunaxid genus from Brazil, Cunaxatricha gen. nov., is erected and its type species, Cunaxatricha tarsospinosa sp. nov. is described and figured. A key to the genera of the subfamily Cunaxinae, to which this new genus belongs, is provided.
\end{abstract}

Key words: Bdelloidea, Cunaxinae, predatory mite, identification key, taxonomy

\section{Introduction}

Members of Cunaxidae are all free-living and predacious, forming an integral part of soil, plant or stored food ecosystems (Meyer \& Ryke 1959, Muma 1960, Gerson et al. 2003). They prey mostly on nematodes and small arthropods, mainly mites and Collembola; some species have also been observed feeding on fungi (Walter \& Kaplan 1991). Three cunaxid species were previously reported from Brazil namely, Cunaxa denmarki Smiley, Scutascirus braziliensis Den Heyer and Dactyloscirus bison (Berlese). Faunistic studies of mites from Brazilian natural ecosystems (Arruda Filho \& Moraes 2002, Zacarias \& Moraes 2002, Castro \& Moraes 2007) and from plants of agricultural importance (Ferla \& Moraes 1998, Feres 2000, Feres et al. 2002, Ferla \& Moraes 2002, Barbosa et al. 2005) reported the Cunaxidae only at generic level. One of these studies reported a considerable diversity of this predatory group in the Atlantic Forest, one of the most important natural ecosystems of Brazil (Castro \& Moraes 2007). In a recent study of the mentioned brazilian cunaxid fauna Den Heyer \& Castro (2008a \& b) revised the genus Pseudobonzia Smiley, divided it and described two new species of a new genus Coleobonzia Den Heyer \& Castro; they also described three new species of Neoscirula Den Heyer. In this paper a new genus found from those natural ecosystems on different plant families of this ecosystems as well as from rubber tree plantations is described.

\section{Material and methods}

Mites were sampled from plants of the Atlantic Forest in Cananéia, Pariquera- Açu and Piracicaba in the State of São Paulo during the Biota project (97/7099-0), and from rubber tree, Hevea brasiliensis Muell. Arg., plantations in Piracicaba and Votuporanga in the State of São Paulo and in Selvíria in the State of Mato Grosso do Sul. 